\title{
Comparison of Methods Used to Separate the Inner and Outer Membranes of Cell Envelopes of Campylobacter spp.
}

\author{
By WILLIAM J. PAGE ${ }^{1 *}$ AND DIANE E. TAYLOR ${ }^{1,2}$ \\ Departments of Microbiology ${ }^{1}$ and Medical Microbiology and Infectious Diseases ${ }^{2}$, \\ University of Alberta, Edmonton, Alberta, Canada T6G $2 E 9$
}

(Received 14 March 1988; revised 13 June 1988)

\begin{abstract}
The outer membrane of Campylobacter coli, C. jejuni and C. fetus cell envelopes appeared as three fractions after sucrose gradient centrifugation. Each outer membrane fraction was contaminated with succinate dehydrogenase activity from the cytoplasmic membrane fraction. Similarly the inner membrane fraction was contaminated with 2-ketodeoxyoctonate and outer membrane proteins including the porin(s). The separation of these two membranes was not facilitated by variations in lysozyme treatment, cell age, presence or absence of flagella, or longer lipopolysaccharide chain length. Sodium lauroyl sarcosinate extraction resulted in an outer membrane fraction which contained some inner membrane contamination and produced multiple bands upon sucrose gradient centrifugation. Triton X-100 extraction removed the inner membrane from the outer membrane and Triton X-100/EDTA treatment extracted lipopolysaccharide-rich regions of the outer membrane which contained almost exclusively the Campylobacter porin(s). These data indicated that the inner and outer membranes of the Campylobacter cell envelope were very difficult to separate, possibly because of extensive fusions between these two membranes.
\end{abstract}

\section{INTRODUCTION}

Campylobacter spp. have become known worldwide as important human enteric pathogens (Walker et al., 1986). With an increased ability to culture and identify these organisms, the study of these pathogens has naturally turned to understanding cell structure and virulence properties. Cell structures that have been recognized as virulence factors include the surface array of serumresistant $C$. fetus (Blaser et al., 1987) and the underlying lipopolysaccharide (LPS) layer, which has long polysaccharide chains (Perez et al., 1985). Serum-sensitive strains of C. fetus, C. coli and C. jejuni all contain 'rough' LPS with short polysaccharide chains (Logan \& Trust, 1984; Perez et al., 1985). All of these campylobacters also lack Braun's lipoprotein, a structural feature of the Escherichia coli and Salmonella typhimurium cell wall involved in anchoring the outer membrane (OM) to the peptidoglycan layer (Logan \& Trust, 1982). Other important surface antigens include the flagellum, its component protein (flagellin) having a $62 \mathrm{kDa}$ molecular mass (Newell et al., 1984; Logan \& Trust, 1984), a $31 \mathrm{kDa}$ acid-extractable protein in $C$. jejuni and $C$. coli (Logan \& Trust, 1983) and the major OM protein (MOMP) at 44-47 kDa. True to the prediction of Logan \& Trust (1984), the MOMP of C. jejuni is the porin protein, although the aqueous channel formed through the $\mathrm{OM}$ is very small in comparison to pores formed by other bacteria (Huyer et al., 1986). Similarly, a mixture of the two MOMPs of $C$. fetus form a relatively large and a smaller pore, and it is presently thought that both MOMPs are porins (Huyer et al., 1986).

\footnotetext{
Abbreviations: OM, outer membrane; MOMP, major outer membrane protein; IM, inner membrane; KDO, 2-ketodeoxyoctonate (3-deoxy-D-manno-2-oculosonate); $\mathrm{SDH}$, succinate dehydrogenase.
} 
The ability to isolate rapidly Campylobacter spp. OM is an essential step in the identification of species and for antigenic analysis. The sodium lauroyl sarcosinate (sarkosyl) extraction method of Filip et al. (1973) is used almost exclusively for this purpose in Campylobacter studies. The assumption is made that Campylobacter cells fractionate like $E$. coli, yielding pure OM with the inner membrane (IM) removed. This study examines the use of sucrose gradient fractionation to prepare OM of Campylobacter spp. and compares these preparations with detergent-extracted OM preparations. A comparison of these techniques provides some insight into the structure of the Campylobacter cell envelope.

\section{METHODS}

Bacterial strains and cultivation. Strains of Campylobacter used in this study included C. jejuni UA580 (NCTC 11168), the flagellate and aflagellate strains of $C$. jejuni 81116 (Newell et al., 1984), a nalidixic acid resistant strain of C. coli, strain UA30 (Taylor et al., 1983) and C. fetus strain UA60. Pseudomonas aeruginosa ATCC 27853 and Escherichia coli $\mathrm{K} 12$ were also used.

Campylobacter spp. were grown in Mueller Hinton medium (Difco) in a solid $(1.8 \% \mathrm{agar}, \mathrm{w} / \mathrm{v})$ or liquid form. $P$. aeruginosa was grown in Trypticase Soy Broth (BBL) and E. coli $\mathrm{K} 12$ was grown in Luria Broth $[1 \%(\mathrm{w} / \mathrm{v})$ bactotryptone (Difco), $0.5 \%$ yeast extract (Difco), $0.5 \% \mathrm{NaCl}$, at $37^{\circ} \mathrm{C}$ for $16 \mathrm{~h}$. Liquid medium for Campylobacter culture $(600 \mathrm{ml})$ was contained in 3 litre Fernbach flasks. The cultures were grown statically at $37^{\circ} \mathrm{C}$ in an atmosphere enriched with $7-8 \% \mathrm{CO}_{2}$, at $85 \%$ humidity. C. coli and $C$. jejuni spiral-shaped cells were harvested from liquid medium after $24 \mathrm{~h}$, whereas $C$. fetus spiral-shaped cells were harvested at $48 \mathrm{~h}$. Predominantly coccoid cells were harvested from agar plates at $72 \mathrm{~h}$. The cells were concentrated by centrifugation, washed once with $8 \mathrm{mM}-\mathrm{Tris} / \mathrm{HCl}, \mathrm{pH} 7.8$, and resuspended in the same buffer.

Cell breakage. Cell-free extracts were prepared by disruption in a French pressure cell as described by Page \& von Tigerstrom (1982).

Sucrose gradient fractionation. Cell envelopes were recovered from the cell-free extract on a cushion of $72 \%(\mathrm{w} / \mathrm{v})$ sucrose according to Page \& von Tigerstrom (1982). The cell envelopes $(1.8 \mathrm{ml})$ were fractionated further on a step gradient (modified from Hancock \& Nikaido, 1978) composed of sucrose (w/v): $72 \%, 1.2 \mathrm{ml} ; 60 \%, 2.0 \mathrm{ml} ; 50 \%$, $2.0 \mathrm{ml} ; 45 \%, 2.0 \mathrm{ml}$; and $40 \%, 2.0 \mathrm{ml}$; in $8 \mathrm{mM}-\mathrm{Tris} / \mathrm{HCl}, \mathrm{pH} 7.8$, and centrifuged $\left(30000\right.$ r.p.m., $\left.16 \mathrm{~h}, 2{ }^{\circ} \mathrm{C}\right)$ in a Beckman SW40Ti rotor.

Isolation of $O M$ fragments. OM fragments also were isolated from cells grown on solid medium by the washing and sedimentation procedure of Logan \& Trust (1982). This procedure involved the washing of cells (that were not deliberately broken) in cold Dulbecco phosphate-buffered saline, $\mathrm{pH} 7.4$ (Oxoid) followed by low speed centrifugation to remove whole cells and a high speed centrifugation $\left(100000 \mathrm{~g}, 2.5 \mathrm{~h}, 5^{\circ} \mathrm{C}\right)$ to sediment $\mathrm{OM}$ fragments.

Detergent extraction. OMs were isolated by selective solubilization of IM in the cell-free extract with sarkosyl as described by Filip et al. (1973). Also OM were prepared by the Triton X-100 fractionation method of Schnaitman (1971) as described by Huyer et al. (1986).

Chemical determinations. Protein content was measured by the Lowry method or by the method of Bradford (1976). LPS was estimated as described by Osborn et al. (1972) with 2-ketodeoxyoctonate (KDO) as a standard. Succinate dehydrogenase (SDH) activity was measured as described by Osborn et al. (1972).

Electrophoresis. SDS-PAGE was conducted as described previously (Page \& von Tigerstrom, 1982). The protein samples $\left(20 \mu \mathrm{g}\right.$ protein per well) were heated in SDS and 2-mercaptoethanol for $5 \mathrm{~min}$ at $100^{\circ} \mathrm{C}$ prior to electrophoresis (Page \& von Tigerstrom, 1982). Proteins were stained with Coomassie brilliant blue R-250 as described by Fairbanks et al. (1971) and molecular masses were determined by comparison to authentic standards (Sigma): phosphorylase $a(94 \mathrm{kDa})$, bovine serum albumin (68 kDa), $\gamma$-globulin H-chain $(50 \mathrm{kDa})$, ovalbumin $(43 \mathrm{kDa}), \gamma$-globulin L-chain $(\sim 24 \mathrm{kDa})$, and lysozyme $(\sim 14 \mathrm{kDa})$.

\section{RESULTS AND DISCUSSION}

\section{Sucrose gradient fractionation}

C. coli and $C$. jejuni (data not shown) membranes were resolved into four major fractions by sucrose gradient centrifugation. The profiles from these two species $(24 \mathrm{~h}$, spiral-shaped cells) were virtually identical in terms of $A_{280}$ and relative density of each fraction. At the bottom of the gradient there was an opaque white band (A) which accounted for the majority of the $A_{280}$ on the gradient (Fig. 1, Table 1). Proceeding up the gradient there was another opaque white band (B), an orange-white band (C), and finally a red-orange band (D). 


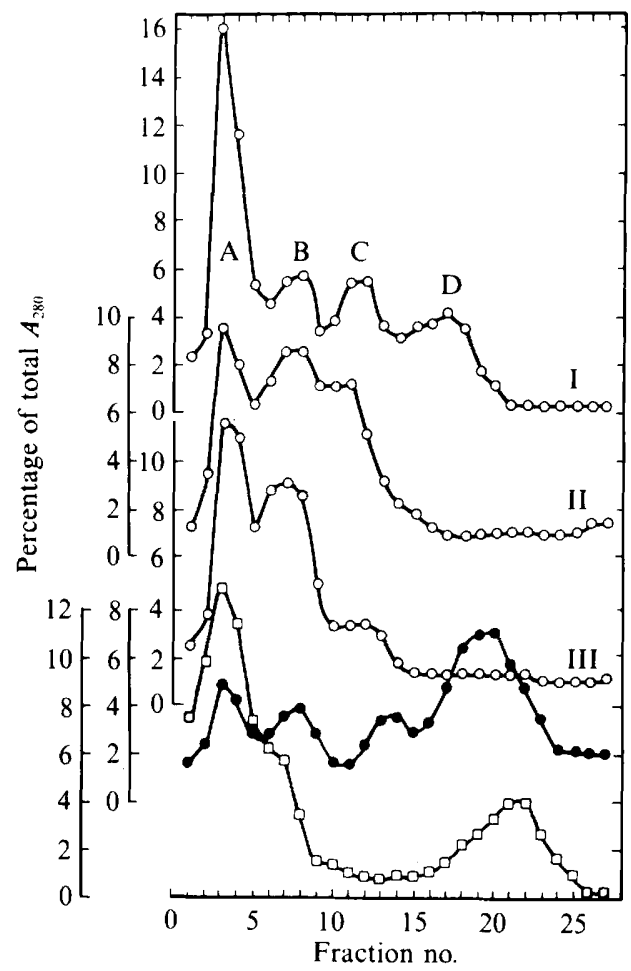

Fig. 1. Separation of $C$. coli IM and OM fractions after sucrose gradient centrifugation. $C$. coli membranes (O) prepared after breakage in the French pressure cell (I), after sarkosyl extraction of cell envelopes (II) or released from washed whole cells (III) were separated on a sucrose step gradient (see Methods). Fraction (0.4 ml each) numbers 3-4 (A), 7-8 (B), 11-12 (C), and 16-18 (D) were collected from the bottom of the gradient and pooled for further analysis. P. aeruginosa ATCC $27853(O)$ and $E$. coli $\mathrm{K} 12(\square)$ cell envelopes also were fractionated on these gradients.

\section{Table 1. Chemical analysis of sucrose gradient fractions of $C$. coli and $C$. fetus membranes}

The data are representative of replicate sets of gradients. The results were reproducible between replicates by $\pm 5-10 \%$. Greater variation existed between duplicate trials but the pattern of fractionation and activities per fraction was constant for each species.

\begin{tabular}{|c|c|c|c|c|c|}
\hline Organism & Fraction & $\begin{array}{l}\text { Percentage } \\
\text { of total } A_{280}\end{array}$ & $\begin{array}{c}\text { Protein } \\
\left(\mathrm{mg} \mathrm{ml}^{-1}\right)\end{array}$ & $\begin{array}{l}\text { SDH specific } \\
\text { activity* }\end{array}$ & $\begin{array}{c}\text { KDO }[\mu \mathrm{g} \\
\left.(\mathrm{mg} \text { protein })^{-1}\right]\end{array}$ \\
\hline C. coli & $\begin{array}{l}\text { A } \\
\text { B } \\
\text { C } \\
\text { D }\end{array}$ & $\begin{array}{l}27.5 \\
11.3 \\
11.2 \\
11.6\end{array}$ & $\begin{array}{l}3.4 \\
5 \cdot 6 \\
2 \cdot 3 \\
2 \cdot 0\end{array}$ & $\begin{array}{r}0.77 \\
1.36 \\
3 \cdot 19 \\
10.08\end{array}$ & $\begin{array}{l}0.65 \\
1.58 \\
3.02 \\
1.78\end{array}$ \\
\hline C. fetus & $\begin{array}{l}\text { A } \\
\text { B } \\
\text { C } \\
\text { D }\end{array}$ & $\begin{array}{l}22 \cdot 5 \\
14 \cdot 1 \\
12 \cdot 4 \\
17 \cdot 6\end{array}$ & $\begin{array}{l}2.4 \\
2.5 \\
1.7 \\
1.7\end{array}$ & $\begin{array}{r}9.8 \\
26.8 \\
57.9 \\
66.4\end{array}$ & $\begin{array}{l}2.63 \\
2.88 \\
2.82 \\
1.49\end{array}$ \\
\hline
\end{tabular}

* Specific activity is expressed as $\Delta A_{600} \min ^{-1}$ (mg protein) $)^{-1}$.

The lower bands (A-C) contained KDO but this OM marker was not exclusively located in these fractions. Additionally all of the fractions contained some SDH activity, and indicated, in the case of $C$. coli, that IM cross-contaminated the OM fractions by approximately $5 \%$, fraction A, $9 \%$, fraction $\mathrm{B}$, and $21 \%$ fraction $\mathrm{C}$. This fractionation pattern was very similar to that obtained with $P$. aeruginosa PAOl by Hancock \& Nikaido (1978). When $P$. aeruginosa 


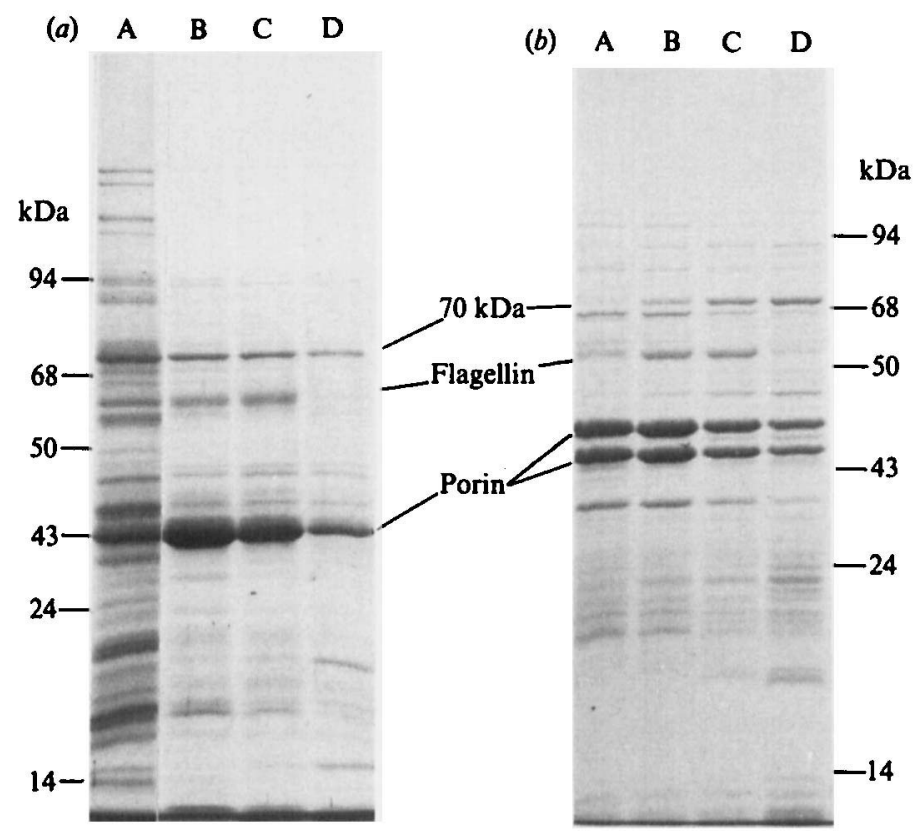

Fig. 2. SDS-PAGE of $C$. coli $(a)$ and $C$. fetus $(b)$ membrane fractions from sucrose gradients. Lanes A$\mathrm{D}$ correspond to the fractions in Fig. 1. Molecular masses of standard proteins are indicated on the left and right.

ATCC 27853 cell walls were fractionated on the sucrose gradients used in the present study, the same pattern of bands was obtained (Fig. 1). These bands, according to KDO and SDH activity (data not shown), corresponded to OM1 (peak fraction 3), OM2 (peak fraction 8), M (peak fractions 13-14) and IM (peak fractions 19-20), using the terminology and criteria of Hancock \& Nikaido (1978). The three most dense bands: OM1, OM2, and M, were contaminated with IM material (as estimated by SDH activity) to the extent of $7 \%, 21 \%$, and $31 \%$, respectively, but the IM fraction contained essentially no KDO (data not shown; Hancock \& Nikaido, 1978). E. coli K 12 cell walls, on the other hand, were clearly separated on these gradients into OM (peak fraction 3) and IM (peak fractions 21-22; Fig. 1), and SDH activity indicated that the OM fraction was contaminated with IM material to the extent of $\leq 5 \%$. From these results, it was tentatively concluded that the Campylobacter membrane fractions $\mathrm{A}, \mathrm{B}$, and $\mathrm{C}$ corresponded to OM material, cross-contaminated with IM material. It also was tentatively concluded that the uppermost fraction $\mathrm{D}$, which contained the majority of the SDH activity, a red-orange (haem) colour, but some KDO, was the IM-enriched fraction.

Further resolution and separation of Campylobacter IM and OM fractions was not possible, despite the use of different sucrose concentrations in the gradient. The position of these bands was not affected by the presence or absence of lysozyme prior to sucrose gradient centrifugation or the use of sonic disruption rather than the French pressure cell (data not shown). Similarly, coccoid cells harvested at $72 \mathrm{~h}$ produced the same pattern of fractionation, with exact coincidence of fractions and identical $A_{280}$ values as reported in Fig. 1 for the $24 \mathrm{~h}$ spiral-shaped cells. $C$. fetus $A_{280}$ profiles from sucrose gradients always showed a more 'saddle-shaped' distribution with greater recovery of $A_{280}$ in the IM fraction (D). The $A_{280}$ profiles and protein contents per fraction also reflected the decreased content of fractions $\mathrm{A}$ and $\mathrm{B}$ in C. fetus (Table 1). The assays of SDH activity and KDO, however, indicated that the membrane fractions were cross-contaminated. Therefore the presence of 'smooth' LPS in C. fetus did not result in better resolution of IM and OM fractions.

Cross-contamination of the membrane fractions also was visible when the sucrose gradient fractions were analysed by SDS-PAGE (Fig. 2). The striking first impression of the gels was the 
great number of protein bands seen in these fractions and the number of proteins common to both the IM and OM fractions. One of these proteins at approximately $70 \mathrm{kDa}$ molecular mass, however, appeared to originate in the IM but was present in the OM as a contaminant (Fig. 2). The MOMP of C. coli, which is the porin (E. A. Worobec \& G. Huyer, unpublished data), was concentrated in fractions B and C, but clearly was present in all the fractions. Flagellin, similarly, was concentrated in fractions B and C (Fig. 2). SDS-PAGE of the sucrose gradient fractions of $C$. fetus membranes also showed that the two MOMPs (presumed porins, Huyer et al., 1986) at $45 \mathrm{kDa}$ and $47 \mathrm{kDa}$ were distributed through all the fractions. These proteins, however, were concentrated in fractions $\mathrm{A}$ and $\mathrm{B}$. This 'movement' of the porins into the more dense fractions of $C$. fetus membranes was like that reported in the comparison of smooth- and rough-LPS mutants of $E$. coli and S. typhimurium (Ames et al., 1974; Koplow \& Goldfine, 1974). There also was a coincidence of the concentration of porin and LPS in the OM fractions of $C$. coli and $C$. fetus (Fig. 2 and Table 1). C. jejuni gave results very similar to C. coli (data not shown). Both flagellate and aflagellate strains of $C$. jejuni produced identical sucrose gradient fractionation and protein patterns upon SDS-PAGE, save the lack of flagellin (data not shown). Ames et al. (1974) suggested that membrane fractions with a density intermediate between OM and IM may exist because of flagellar attachment. Similar fractionation profiles between flagellate and aflagellate strains, however, indicated that this was not the reason for fractions $B$ and $\mathrm{C}$ in $C$. jejuni.

From these data it was clear that the IM and OM of C. coli, C. jejuni and C. fetus were not being separated upon sucrose gradient centrifugation. This possibly was due to entrapment and cosedimentation of IM and OM vesicles, or due to physical adhesion of the two membranes (Osborn et al., 1972; Schnaitman, 1970; White et al., 1972). Two approaches were taken to attempt to resolve these possibilities: (a) the examination of OM fragments released during the growth of Campylobacter and (b) the selective removal of IM material by dissolution in the detergents sarkosyl or Triton X-100.

\section{OM fragments released from whole cells}

Sucrose gradient centrifugation of $\mathrm{OM}$ fragments released from whole cells of $C$. coli revealed the absence of fraction D and the presence of a band slightly less dense than fraction C (Fig. 1). The three bands, however, were contaminated with SDH activity and the protein profile on SDS-PAGE showed the presence of MOMP, flagellin, a great variety of minor proteins, and the $70 \mathrm{kDa}$ IM protein (Fig. 3). Therefore, this material was cell envelope fragments rather than true OM fragments. This material possibly originated from the degenerate coccoid cells which are osmotically fragile (Moran \& Upton, 1986) and frequently demonstrate plasmolysis and lysis (Moran \& Upton, 1987; Ng et al., 1985; Rollins \& Colwell, 1986).

\section{Treatment of cell envelopes with sarkosyl}

OM prepared by sarkosyl extraction of $C$. coli cell envelope material also was composed of three types of membrane fragments that separated on sucrose gradients as fractions A, B and C (Fig. 1). The IM, fraction D was missing as expected. SDS-PAGE of these preparations showed the presence of many proteins, including MOMP and flagellin (Fig. 3). A small amount of SDH activity occurred in all the fractions (data not shown) but the $70 \mathrm{kDa}$ IM protein was notably absent. The number of proteins present in fraction A (Fig. 2) was greatly reduced after sarkosyl extraction (Fig. 3) with a corresponding decrease in $A_{280}$ (Fig. 1), which indicated that this fraction also had been significantly contaminated with IM material.

\section{Triton/EDTA extraction}

Triton/EDTA extraction of $C$. coli cell envelopes separated the MOMP from the other proteins present in the membrane mixture (Fig. 4). The Triton-soluble, presumptive IM fraction (Schnaitman, 1971), contained a variety of proteins, notably the presence of the $70 \mathrm{kDa}$ protein and absence of flagellin and the MOMP. These latter proteins remained in the Triton-insoluble, presumptive OM material (Schnaitman, 1971). Further extraction with Triton/EDTA fractionated the Triton-insoluble material into the Triton/EDTA-insoluble fraction, which 


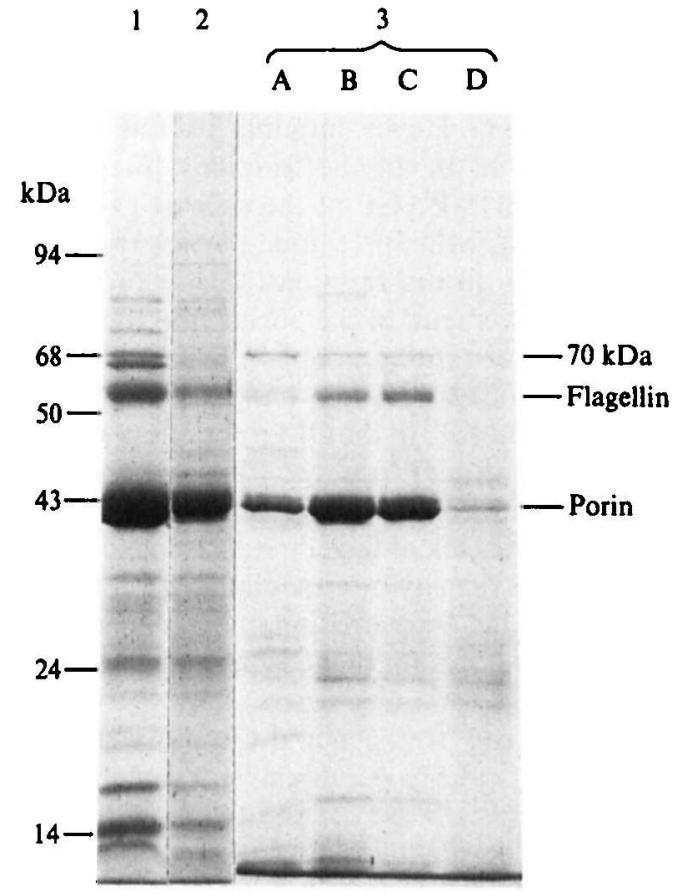

Fig. 3

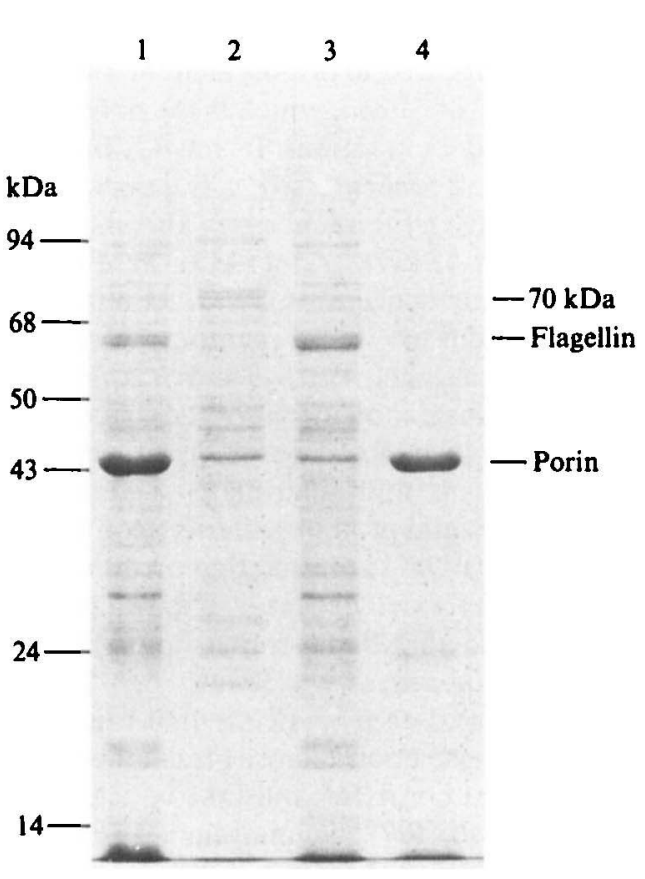

Fig. 4

Fig. 3. SDS-PAGE of C. coli OM fragments and OM prepared by sarkosyl extraction. OM fragments washed from whole cells (1), OM prepared by sarkosyl extraction (2), and fractions from sucrose gradient fractionation of sarkosyl-extracted cell envelopes (3) were applied at $20 \mu \mathrm{g}$ protein per well, except in the case of lane 3D, which contained very little protein (see Fig. 1), where only $<5 \mu \mathrm{g}$ protein could be applied to the gel. In (3), lanes A-D correspond to the fractions in Fig. 1. Molecular masses of standard proteins are indicated on the left.

Fig. 4. Triton/EDTA fractionation of $C$. coli envelopes. Lanes: 1, Triton-insoluble OM material; 2 , Triton-soluble IM material; 3, Triton/EDTA-insoluble OM material; and 4, Triton/EDTA-soluble OM material. The membrane material was applied at $20 \mu \mathrm{g}$ protein per well. Molecular masses of standard proteins are indicated on the left.

contained flagellin and other proteins, some of which were shared with the Triton-soluble fraction, and the Triton/EDTA-soluble fraction, which contained the MOMP (porin) as an essentially pure protein (Fig. 4). This Triton/EDTA fractionation procedure has been used previously to selectively extract the MOMPs (presumed porins) of $C$. fetus and the porin of $C$. jejuni (Huyer et al., 1986).

Chemical analysis revealed that the Triton/EDTA-soluble fraction from C. coli, $C$. jejuni and C. fetus contained $7.8,11.8$, and $33.9 \mu \mathrm{g}$ KDO (mg protein) ${ }^{-1}$, respectively. The Triton-soluble fraction contained 0 to $0.7 \mu \mathrm{g} \mathrm{KDO}$ (mg protein $)^{-1}$ and the only detectable SDH activity. The Triton/EDTA-insoluble fraction contained a large amount of protein and relatively little KDO [ 1.3 to $\left.3.4 \mu \mathrm{g} \mathrm{KDO} \mathrm{(mg} \mathrm{protein)}{ }^{-1}\right]$.

We conclude that the fractionation of Campylobacter membranes by sucrose gradient fractionation and sarkosyl extraction did not clearly eliminate IM contamination of the OM fractions. The appearance of multiple $O M$ fractions after sucrose gradient fractionation was more like that obtained with $P$. aeruginosa (this study; Hancock \& Nikaido, 1978) than with $E$. coli $\mathrm{K} 12$. In Campylobacter spp. and $P$. aeruginosa the multiple forms of OM appear to be due to IM contamination. However, in the case of Campylobacter the IM is significantly contaminated with $\mathrm{OM}$ porin protein(s) and $\mathrm{KDO}$, while in $P$. aeruginos $a$ the IM is essentially free of KDO and OM proteins (Hancock \& Nikaido, 1978). This cross-contamination of membrane fractions was unlikely to be due to physical entrapment of membrane vesicles, because sarkosyl extraction removed the IM fraction, but did not result in a single OM fraction. 
A possible explanation for these results is that the Campylobacter IM and OM are fused at numerous places, and that these in turn may stabilize the cell envelope of these lipoproteindeficient cells. Sarkosyl extraction may remove IM 'patches' but may leave the membrane fusions in the OM preparation. This results in a complex OM preparation that contains many proteins, but only a few may be truly of OM origin. The other method of selective membrane solubilization, Triton X-100 extraction appeared to be more efficient in removing IM material containing SDH activity from the OM fraction. Triton/EDTA extraction then appeared to remove LPS-rich OM 'patches' containing porin, leaving the majority of the proteins including flagellin in the Triton/EDTA-insoluble material.

The coincidence of porin and LPS, and the distribution of porin through the sucrose gradient fractions is strongly suggestive of extensive adhesions between the OM and IM of the Campylobacter cell wall (Bayer, 1979; Smit \& Nikaido, 1978). It is interesting that attempts to plasmolyse the spiral forms of Campylobacter spp. have been unsuccessful (L.- K. Ng, personal communication), which may be a consequence of the proposed extensive fusion between the IM and OM. Coccoid forms, however, frequently appear 'plasmolysed' in routine preparations (Buck, et al., 1983; Ng et al., 1985; Moran \& Upton, 1987), but this 'plasmolysis' is accompanied by visible damage to both the OM and IM (Moran \& Upton, 1987) and the leakage of cytoplasmic constituents (Moran \& Upton, 1986). These observations also support the possibility of extensive fusions between the IM and $O M$ and indicate that separation may be difficult or impossible without severe damage to membrane integrity. The distinction between viable but non-culturable coccoid cells (Rollins \& Colwell, 1986) and non-viable coccoid cells may depend on the extent to which the OM and IM are torn apart during conversion to the coccoid form. The possibility of extensive adhesions between the IM and OM also may have important consequences on the uptake and export of hydrophobic compounds (as reviewed by Nikaido \& Vaara, 1985) by these species of Campylobacter.

We are grateful to the Alberta Heritage Fund for Medical Research for supporting this study through studentships to the excellent undergraduate summer assistants Marianne Huyer, Dana Smith, Ted Yoo, and Mark Wigmore who were involved with this study. We thank Lai-King $\mathrm{Ng}$ for technical advice and Virginia Kervin for her typing skills. Operating funds were obtained by W. J.P. from the Natural Sciences and Engineering Research Council of Canada.

\section{REFERENCES}

Ames, G. F.-L., SPUdich, E. N. \& Nikaido, H. (1974). Protein composition of the outer membrane of Salmonella typhimurium: effect of lipopolysaccharide mutations. Journal of Bacteriology 117, 406416.

BAYER, M. E. (1979). The fusion sites between outer membrane and cytoplasmic membrane of bacteria : their role in membrane assembly and virus infection. In Bacterial Outer Membranes. Biogenesis and Functions, pp. 167-202. Edited by M. Inouye. New York: John Wiley.

Blaser, M. J., Smith, P. F., Hopkins, J. A., Heinzer, I., BRYNer, J. A. \& WANG, W.-L. L. (1987). Pathogenesis of Campylobacter fetus infections: serum resistance associated with high-molecularweight surface proteins. Journal of Infectious Diseases 155, 696-705.

BRADFORD, M. M. (1976). A rapid and sensitive method for the quantitation of microgram quantities of protein utilizing the principle of protein-dye binding. Analytical Chemistry 72, 248-254.

Buck, G. E., Parshall, K. A. \& Davis, C. P. (1983). Electron microscopy of the coccoid form of Campylobacter jejuni. Journal of Clinical Microbiology 18, 420421.
Fairbanks, G., Steck, T. L. \& Wallach, D. F. H. (1971). Electrophoretic analysis of major polypeptides of the human erythrocyte membrane. Biochemistry 10, 2606-2616.

Filip, C., Fletcher, G., WulfF, J. L. \& Earhart, C. F. (1973). Solubilization of the cytoplasmic membrane of Escherichia coli by the ionic detergent sodium-lauryl sarcosinate. Journal of Bacteriology $115,717-722$.

Hancock, R. E. W. \& Nikaido, H. (1978). Outer membranes of Gram-negative bacteria. XIX. Isolation from Pseudomonas aeruginosa PAOl and use in reconstitution and definition of the permeability barrier. Journal of Bacteriology 136, 381-390.

HuYer, M., ParR, T. R., JR, Hancock, R. E. W. \& PAGE, W. J. (1986). Outer membrane porin protein of Campylobacter jejuni. FEMS Microbiology Letters 37, 247-250.

Koplow, J. \& GoldFine, H. (1974). Alterations in the outer membrane of the cell envelope of heptosedeficient mutants of Escherichia coli. Journal of Bacteriology 117, 527-543.

LoGAN, S. M. \& TRUST, T. J. (1982). Outer membrane characteristics of Campylobacter jejuni. Infection and Immunity 38, 898-906. 
LogAN, S. M. \& Trust, T. J. (1983). Molecular identification of surface protein antigens of Campylobacter jejuni. Infection and Immunity 42, 675-682.

LOGAN, S. M. \& TRUST, T. J. (1984). Structural and antigenic heterogeneity of lipopolysaccharides of Campylobacter jejuni and Campylobacter coli. Infection and Immunity 45, 210-216.

MoRAN, A. P. \& UPTON, M. E. (1986). A comparative study of the rod and coccoid forms of Campylobacter jejuni ATCC 29428. Journal of Applied Bacteriology 60, 103-110.

Moran, A. P. \& UPTON, M. E. (1987). Factors affecting production of coccoid forms of Campylobacter jejuni on solid media during incubation. Journal of Applied Bacteriology 62, 527-537.

Newell, D. G., McBride, H. \& Pearson, A. D. (1984). The identification of outer membrane proteins and flagella of Campylobacter jejuni. Journal of General Microbiology 130, 1201-1208.

Ng, L.-K., Sherburne, R., Taylor, D. E. \& Stiles, M. E. (1985). Morphological forms and viability of Campylobacter species studied by electron microscopy. Journal of Bacteriology 164, 338-343.

NikAIDO, H. \& VAARA, M. (1985). Molecular basis of bacterial outer membrane permeability. Microbiological Reviews 49, 1-32.

Osborn, M. J., GANDer, J. E., Parisi, E. \& Carson, J. (1972). Mechanism of assembly of the outer membrane of Salmonella typhimurium: isolation and characterisation of cytoplasmic and outer membrane. Journal of Biological Chemistry 247, 39623972.

Page, W. J. \& von Tigerstrom, M. (1982). Iron- and molybdenum-repressible outer membrane proteins in competent Azotobacter vinelandii. Journal of Bacteriology 151, 237-242.
Perez, G. I. P., Hopkins, J. A. \& Blaser, M. (1985). Antigenic heterogeneity of lipopolysaccharides from Campylobacter jejuni and Campylobacter fetus. Infection and Immunity 48, 528-533.

Rollins, D. M. \& Colwell, R. R. (1986). Viable but non culturable stage of Campylobacter jejuni and its role in survival in the natural aquatic environment. Applied and Environmental Microbiology 52, 531-538.

Schnaitman, C. A. (1970). Protein composition of the cell wall and cytoplasmic membrane of Escherichia coli. Journal of Bacteriology 104, 890-891.

SchNaItMan, C. A. (1971). Effect of ethylenediaminetetraacetic acid, Triton X-100, and lysozyme on the morphology and chemical composition of isolated cell walls of Escherichia coli. Journal of Bacteriology 108, 553-563.

SMrT, J. \& NiKaIDO, H. (1978). Outer membrane of Gram-negative bacteria. XVIII. Electron microscopic studies on porin insertion sites and growth of cell surface of Salmonella typhimurium. Journal of Bacteriology 135, 687-702.

TaYlor, D. E., Garner, R. S. \& Allan, B. J. (1983). Characterization of tetracycline resistance plasmids from Campylobacter jejuni and Campylobacter coli. Antimicrobial Agents and Chemotherapy 24, 930-935.

Walker, R. I., CaldWell, M. B., Lee, E. C., Guerry, P., Trust, T. J. \& Ruiz-Palacios, G. M. (1986). Pathophysiology of Campylobacter enteritis. Microbiological Reviews 50, 81-94.

White, D. A., Lennarz, W. J. \& Schnaitman, C. A. (1972). Distribution of lipids in the wall and cytoplasmic membrane subfractions of the cell envelope of Escherichia coli. Journal of Bacteriology 109, 686-690. 